\title{
Ichneumonids (Hymenoptera) and Tachinid Flies (Diptera) Associated to Leptidopterans in Soybean Crops
}

\author{
Angélica Massarolli ${ }^{1}$, Ana Regina Lucena Hoffmann ${ }^{2}$, Bruna Magda Favetti ${ }^{3} \&$ Alessandra Regina Butnariu ${ }^{4}$ \\ ${ }^{1}$ Departamento de Zoologia, Universidade Federal do Paraná, Curitiba, PR, Brazil \\ ${ }^{2}$ Bióloga Autônoma, Mestre em Ambiente e Sistemas de Produção Agrícola, Brazil \\ ${ }^{3}$ Instituto Agronômico do Paraná, Londrina, PR, Brazil \\ ${ }^{4}$ Departamento de Ciências Biológicas, Universidade do Estado de Mato Grosso, Campus de Tangará da Serra, \\ Brazil \\ Correspondence: Angélica Massarolli, Departamento de Zoologia, Universidade Federal do Paraná, Curitiba, PR, \\ Brazil. Tel: 55-81531-980. E-mail: angelicamassaroli@gmail.com
}

Received: March 4, 2018

doi:10.5539/jas.v10n7p167
Accepted: April 28, $2018 \quad$ Online Published: June 15, 2018

URL: https://doi.org/10.5539/jas.v10n7p167

\begin{abstract}
Studies on natural enemies are important to find new species and to develop management strategies to preserve them to help control pests in biological control programs. For the state of Mato Grosso, Brazil, which comprises the Amazon, Cerrado, and Pantanal biomes, few studies have been conducted on the diversity of these parasitoids, possible endemic and/or new species, as well as their potential as natural enemies. Thus, the present study was aimed at describing the diversity of parasitoids of the families Ichneumonidae (Hymenoptera) and Tachinidae (Diptera) associated with pest lepidopterans in soybean crops. Weekly sampling of pest lepidopterans was carried out during four soybean seasons (2009/2010, 2010/2011, 2011/2012 and 2012/2013). Parasitoid larvae were observed in the main lepidopteran pest species of soybean during the four soybean seasons. Three genera of the Ichneumonidae family, belonging to the genera Microcharops Roman, Ophionellus Westwood, and Podogaster Brullé. Six genera of the Tachinidae family occur in the state of Mato Grosso in soybean fields. The following genera were recorded: Archytas spp. Jaennicke, Phorocera spp. Robineau-Desvoidy, Gymnocarcelia spp. Townsend, Lespesia spp. Robineau-Desvoidy, Eucelatoria spp. Townsend, Chetogena spp. Rondani. These parasitoids were found parasitizing caterpillars of the Noctuidae (Lepidoptera), in species that had not yet been reported as hosts for the Neotropical region. Further studies are needed on the beneficial entomofauna and their preservation in agricultural environments.
\end{abstract}

Keywords: Microcharops, Ophionellus, Podogaster, Archytas, Lespesia, Eucelatoria

\section{Introduction}

Soybean (Glycine max L.) is the main crop of the Brazilian agribusiness, covering an area of 33.9 million hectares. The 2016/2017 crop totaled 114 million tons of soybeans, with the state of Mato Grosso as the largest producer, accounting for approximately $27 \%$ of this total (CONAB, 2017). However, phytosanitary problems in the state, such as pest lepidopterans that attack leaves and pods, reduce the production and the quality of soybeans. In general, chemical control is carried out, often not selective to natural enemies, reducing their population and increasing pest unbalance. Knowledge on the natural enemies associated with phytophagous insects of soybean plants is still scarce, especially regarding biological agents associated with pest lepidopterans, such as wasps of the family Ichneumonidae (Hymenoptera) and flies of the family Tachinidae (Diptera).

Among parasitoids of lepidopteran larvae, the Ichneumonidae family is of special interest. It is one of the largest insect families comprised of an estimated 100.000 species (Gauld, 2002). The Tachinidae is the second largest family of parasitic flies, with approximately 10.000 described species (Stireman III et al., 2006), and also includes parasitoids of lepidopterans. Studies on their hosts, behavior, and habitats of species of this family have been carried out in more detail in Europe (Stireman III et al., 2006), while other studies addressed the potential of tachinid flies (Simões et al., 2002). However, few records are available for parasitoids of this family in Brazil, and none exist for the state of Mato Grosso. The diversity of these parasitoids is influenced by the local 
biodiversity and the environment surrounding the agroecossystem, as well as management practices (Chay-Hernandez et al., 2006).

In monocultures, studies tend to underestimate the diversity of parasitoid species, since host diversity will also be limited in a crop (Altieri et al., 2003). In addition, natural enemies are less frequent in annual crops, because each year they need to recolonize the area after the off-season, except where conditions allow the maintenance of species. Despite that, studies on natural enemies are especially important to find new species and to develop management strategies to preserve them to help control pests in biological control programs. For the state of Mato Grosso, which comprises the Amazon, Cerrado, and Pantanal biomes, few studies have been conducted on the diversity of these parasitoids, possible endemic and/or new species, as well as their potential as natural enemies. Thus, the present study was aimed at describing the diversity of parasitoids of the families Ichneumonidae and Tachinidae associated with pest lepidopterans in soybean crops.

\section{Material and Methods}

Weekly sampling of pest lepidopterans was carried out during four soybean seasons (2009/2010, 2010/2011, 2011/2012 and 2012/2013) from December to February of each year in the municipality of Tangará da Serra, MT $\left(14^{\circ} 18^{\prime} 44^{\prime \prime} \mathrm{S}\right.$ and $\left.57^{\circ} 45^{\prime} 18^{\prime \prime} \mathrm{W}\right)$.

The sampling methods used were beat sheet (20 sheets per hectare) and visual search for 2 hours. Specimens were stored in plastic containers $(145 \mathrm{ml})$ and taken to the Laboratory of Entomology of the Research Center for Agro-Environmental Development of the State University of Mato Grosso, campus of Tangará da Serra, MT. In the laboratory, caterpillars were classified with the aid of an identification guide (Sosa-Gómez et al., 2010) and placed in individual tubes. Specimens collected during the first three growing seasons were fed a natural diet (soybean leaves), while those collected during the last crop were fed an artificial diet (Greene et al., 1976). Caterpillars were monitored daily to check of parasitism. Newly emerged parasitoids were preserved in $70 \%$ ethanol and then identified at the lowest taxonomic level possible.

\section{Results}

Parasitoid larvae were observed in the main lepidopteran pest species of soybean during the four soybean seasons (Tables 1 and 2).

\subsection{Ichneumonid Parasitoids (Hymenoptera)}

In the first season (2009/2010), 401 caterpillars were collected and none showed signs of parasitism by ichneumonid wasps. In the 2010/2011 season, 367 caterpillars were sampled and six specimens had parasitoids from this family. In the following season (2011/2012), 1948 caterpillars were collected and only one was parasitized. In the 2012/2013 season, 498 caterpillars were collected and seven were parasitized (Table 1).

Table 1. Species of Noctuidae (Lepidoptera) sampled during soybean season and their parasitoids of the family Ichneumonidae (Hymenoptera) in Tangará da Serra, MT

\begin{tabular}{lllc}
\hline Season & Host & Subfamily/Genus & $\mathbf{N}^{\mathbf{0}}$ \\
\hline $\mathbf{2 0 0 9 / 2 0 1 0}$ & No parasitoids of this family were recorded & & 0 \\
\hline $\mathbf{2 0 1 0} / \mathbf{2 0 1 1}$ & Chrysodeixis includens & Campopleginae/Microcharops sp. & 1 \\
& & Anomaloninae/Ophionellus sp. & 4 \\
& & Anomaloninae/Podogaster sp. & 1 \\
\hline $\mathbf{2 0 1 1 / 2 0 1 2}$ & Chrysodeixis includens & Anomaloninae/Ophionellus sp. & 1 \\
\hline $\mathbf{2 0 1 2 / 2 0 1 3}$ & Chloridea virescens & Anomaloninae/Ophionellus sp. & 5 \\
& Spodoptera cosmioides & Unidentified & 2 \\
\hline Total parasitoids & & 14 \\
\hline
\end{tabular}

The parasitoids sampled belonged to the genera Microcharops Roman, Ophionellus Westwood, and Podogaster Brullé, representing two subfamilies: Campopleginae, recorded only in the 2010/2011 season and Anomaloninae, in the three crops examined.

In the first and second seasons, Ichneumonid wasps were only found in the host species Chrysodeixis includens (Walker) (Lepidoptera: Noctuidae). In the third season, parasitism was observed in Chloridea virescens (Fabricius) (Lepidoptera: Noctuidae), and Spodoptera cosmioides (Walker) (Lepidoptera: Noctuidae), although the number of parasitized $C$. includens caterpillars sampled was higher than those of other species. Of the 498 
caterpillars collected, 329 were identified as C. includens, 85 C. virescens, 69 Spodoptera sp., and 15 Anticarsia gemmatalis Hübner (Lepidoptera: Noctuidae). This is the first record of the occurrence of the genus Ophionellus sp. parasitazing $C$. includens and $C$. virescens in Brazil.

\subsection{Tachinid Parasitoids}

Tachinid flies parasitizing caterpillars of soybeans are reported here for the first time for the state of Mato Grosso. Of the 401 caterpillars collected in the first season (2009/2010), five were parasitized by tachinid flies. In the next season (2010/2011), 12 caterpillars were parasitized from a total of 367 collected. In the 2011/2012 season, of the 1948 caterpillars sampled, five were parasitized. In the last growing season (2012/2013), of the 498 caterpillars collected, eight parasitoids of this family were recorded (Table 2).

Table 2. Species of Noctuidae (Lepidoptera) sampled during four soybean seasons and their parasitoids of the family Tachinidae (Diptera) in Tangará da Serra, MT

\begin{tabular}{|c|c|c|c|}
\hline Season & Host & Subfamily/Tribe/Genus & $\mathbf{N}^{\mathbf{0}}$ \\
\hline \multirow{4}{*}{$2009 / 2010$} & Anticarsia gemmatalis & Archytas spp. & 2 \\
\hline & & Phorocera sp. & 1 \\
\hline & & Unidentified & 1 \\
\hline & Chrysodeixis includens & Tribe Blondeliini & 1 \\
\hline \multirow[t]{5}{*}{$2010 / 2011$} & Chrysodeixis includens & Lespesia spp. & 2 \\
\hline & & Eucelatoria spp. & 3 \\
\hline & & Archytas spp. & 4 \\
\hline & Spodoptera sp. & Eucelatoria spp. & 2 \\
\hline & Unidentified caterpillar & Gymnocarcellia sp. & 1 \\
\hline $2011 / 2012$ & Chrysodeixis includens & Unidentified & 5 \\
\hline \multirow[t]{4}{*}{$2012 / 2013$} & Chrysodeixis includens & Lespesia spp. & 5 \\
\hline & & Phorocera sp. & 1 \\
\hline & & Chetogena sp. & 1 \\
\hline & & Unidentified & 1 \\
\hline Total paras & & & 30 \\
\hline
\end{tabular}

Tachinid parasitoids are difficult to identify, mainly due to the low number of specimens usually obtained. In this study, specimens of the Tribe Blondeliini and of the following genera were recorded: Archytas spp. Jaennicke, Phorocera spp. Robineau-Desvoidy, Gymnocarcelia spp. Townsend, Lespesia spp. Robineau-Desvoidy, Eucelatoria spp. Townsend, Chetogena spp. Rondani. Some specimens could only be identified at the family level (Table 2).

\section{Discussion}

The occurrence and diversity of insects of agricultural importance in a region are associated with the density and biodiversity of existing hosts (Onody, 2005). Studies on the entomofauna are important to expand the knowledge on the biodiversity of agroecosystems and to provide a framework for integrated pest management, since several beneficial insects, such as ichneumonid and tachinid parasitoids, can be used in biological control.

In the present study, ichneumonids were found parasitizing species in soybean fields, which had not yet been reported in Brazil. The low number of parasitoids compared to the number of caterpillars collected may have occurred because soybean is an annual crop and parasitoids need to recolonize the area every growing season. In addition, extensive areas planted with soybean and low plant diversity in the environment may also contribute to decrease the diversity and abundance of natural enemies (Hooks \& Johnson 2003; Lavandero et al., 2006; Shennan, 2008). Another factor to be considered is the type of management practices. The conventional practices in the study area uses chemical products that often follow a predetermined schedule regardless of pest density (control level). Also, a mixture of pesticides may be used and cause a "hitchhiking effect", which can be harmful to ichneumonids, as well as to other beneficial agents (Bueno et al., 2012).

Few studies have been conducted on ichneumonids in the neotropics, such as those by Gauld (1991, 1997), Lanfranco (1974a, 1974b), Jerez et al. (1977), Porter (1975, 1979). In Brazil, ichneumonids have been reported in geometrid caterpillars (Lepidoptera) collected in areas of Cerrado in São Carlos, SP (Braga et al., 2001; 
Marconato et al., 2008), while Kumagai and Graf (2000), in Curitiba, PR, and Kumagai (2002) in Belo Horizonte, MG, collected ichneumonids using flight interception traps, among other studies (Sandonato et al., 2010; Onody \& Penteado-Dias, 2016).

Ichneumonid parasitoids from two subfamilies were collected: Campopleginae, recorded only during the first growing seasons, and Anomaloninae, in the three crops examined. Campopleginae parasitoids are important in the control of insect populations and their larvae are cenobiont endoparasitoids, mainly of caterpillars, which are widely known as agricultural pests (Onody, 2005; Sandonato et al, 2010). In the Neotropical region, 21 genera of Campopleginae have been recorded and of these, 18 occur in Brazil (De Santis, 1980; Graf \& Kumagai, 1997; Kumagai \& Graf, 2000; Yu et al., 2012; Onody \& Penteado-Dias, 2006). While Anomaloninae is a cosmopolitan subfamily and includes cenobiont endoparasitoids of lepidopteran larvae and coleopteran, sixteen genera of this subfamily occur in the neotropical region and seven in Brazil (Yu et al., 2012). Tachinid flies are endoparasitoids that have insects of eight orders as hosts (Wood \& Zumbado, 2010).

In Lepidoptera, tachinid flies are naturally occurring beneficial agents with potential for biological pest control (Stireman et al., 2006; Nihei \& Pavarini, 2011). Although tachinid flies comprise more than 1.500 known genera (O'Hara, 2012), only six have been recorded in this study. The genus Archytas has approximately 15 species, with native flies from North America and South America (Elliott et al., 2017). They are parasites of several families of lepidopterans such as Noctuidae, Notodontidae, Arctiidae, Lasiocampidae, among others (Tachinidae Resources, 2017). Archytas sp. (Lepidoptera: Noctuidae) has been recorded in soybean fields in the state of Minas Gerais, Brazil (Lopes-da-Silva et al., 2014), confirming that this genus is associated with caterpillars of this crop in Brazil. Lespesia is one of the largest and most important of Tachinidae, with 66 known species, of which 37 occur in the neotropical region (Toma, 2010). Records indicate that their hosts include the families Noctuidae, Notodontidae, Saturniidae, and Sphingidae (Wood \& Zumbado, 2010), but studies conducted in South America are still scarce (Gil-Santana et al., 2014). Chetogena consists of 22 species known to occur in the neotropics (Nihei, 2015), including endoparasitoids that attack several groups of insects and mainly several families of Lepidoptera (Sourokov \& Mitchell, 2002; Stireman \& Singer, 2003a, 2003b). Eucelatoria, on the other hand, is a genus that cluster parasites of lepidopterans of the Noctuidae family, especially of the genus Chloridea, Spodoptera, Pseudaletia, Leucania, Mocis, Trichoplusia and occasionally other lepidopteran families (Sabrosky, 1981). And the genus Gymnocarcelia comprises species of parasites used in biological control programs in forestry management, fruticulture, horticulture, and other agricultural crops, parasitizing insect species of various orders such as Hemiptera, Orthoptera, Lepidoptera and Coleoptera (Sánchez-Arias et al., 2017).

Worldwide, there is a high diversity of tachinid flies, however, species identification is difficult, especially in the west. Inclán and Stireman (2014) point out that the tropics of the New World are the most diverse region for tachinid parasitoids, but also have the most closely defined genera of tachinids as well as the most confusing ones of any biogeographic region. Thus, the species found in the present study were identified at the genus level. Further studies are needed to provide in-depth knowledge on the Brazilian tachinid species with potential use in pest control. The natural occurrence of parasitoids in agroecosystems is essential to assist the control of pest populations and consequently reduce yield losses. Menezes (2005) points out that biological control programs require the maintenance of natural enemies in the agroecosystem by preserving and managing habitats, and providing conditions for their survival and reproduction. However, in order to develop these programs, knowledge on the composition and behavior of local natural enemies is needed.

We conclude that three genera of the Ichneumonidae family and six genera of the Tachinidae family occur in the state of Mato Grosso in soybean fields. These genera were found parasitizing caterpillars of the Noctuidae family, in species that had not yet been reported as hosts for the Neotropical region. Further studies are needed on the beneficial entomofauna and their preservation in agricultural environments.

\section{Acknowledgements}

The authors thank the Mato Grosso State University campus of Tangará da Serra and the Mato Grosso Research Foundation for financial assistance to conduct this study (Edital Universal/FAPEMAT-002/2007), the team of the Laboratory of Entomology of the Research Center for Agro-Environmental Studies and Development, the Franciosi Group that allowed collections to be carried out on its property, and the taxonomists: phD Angélica Maria Penteado Dias and phD Helena Carolina Onody of the Department of Ecology and Evolutionary Biology, Federal University of São Carlos, São Carlos, SP for the identification of ichneumonids and phD Enio Nunez for the identification of tachinid flies. 


\section{References}

Altieri, M. A., Silva, E. N., \& Nicholls, C. I. (2003). O papel da biodiversidade no manejo de pragas. Ribeirão Preto: Holos.

Braga, S. M. P., Dias, M. M., \& Penteado-Dias, A. M. (2001). Aspectos bionômicos de Eois tegularia (Guenée) e Eois glauculata (Walker) (Lepidoptera, Geometridae, Larentiinae) e seus parasitóides. Revista Brasileira de Zoologia, 18, 837-840. https://doi.org/10.1590/S0101-81752001000300019

Bueno, A. F., Sosa-Gómez, D. R., Corrêa-Ferreira, B. S., Moscardi, F., \& Bueno, R. C. O. F. (2012). Inimigos naturais das pragas da soja. In C. B. Hoffmann-Campo, B. S. Corrêa-Ferreira, \& F. Moscardi (Eds.), Soja: Manejo integrado de insetos e outros Artrópodes-praga (pp. 493-630). Brasília, DF: Embrapa.

Chay-Hernandez, D. A., Delfin-Gonzalez, H., \& Parra-Tabla, V. (2006). Ichneumonoidae (Hymenoptera) Community Diversity in an Agricultural Environment in the State of Yucatan, Mexico. Environmental Entomology, 35, 1286-1297. https://doi.org/10.1093/ee/35.5.1286

CONAB (Companhia Nacional de Abastecimento). (2017). Acompanhamento da safra brasileira de grãos. Safra 2016/17, $\mathrm{n}^{\circ}$ 11-Décimo Primeiro Levantamento. Retrieved October 30, 2017, from http://www.conab. gov.br/OlalaCMS/uploads/arquivos/17_08_10_11_27_12_boletim_graos_agosto_2017.pdf

De Santis, L. (1980). Catalogo de los himenopteros brasilenõs de la serie Parasitica, incluyendo Bethyloidea. Universidade Federal do Paraná, Curitiba.

Elliott, L. (2017). BugGuide: Genus Archytas. Iowa State University, Department of Entomology. Retrieved January 5, 2018, from http://bugguide.net/node/view/21091

Gauld, I. D. (1991). The Ichneumonidae of Costa Rica, 1. Memoirs of the American Entomological Institute, 47, $1-589$.

Gauld, I. D. (1997). The Ichneumonidae of Costa Rica, 2. Memoirs of the American Entomological Institute, 57, $1-485$.

Gauld, I. D., Godoy, C., Sithole, R., \& Gómez, J. U. (2002). The Ichneumonidae of Costa Rica, 4. Memoirs of the American Entomological Institute, 66, 1-768.

Gil-Santana, H. R., Nihei, S. S., \& Nunez, E. (2014). Lespesia melloi sp. nov. (Diptera: Tachinidae) from Brazil, a parasitoid of Xanthopastis timais (Lepidoptera: Noctuidae). Journal of Insect Science, 14, 121. https://doi.org/10.1093/jis/14.1.121

Graf, V., \& Kumagai, A. F. (1997). Novo gênero de Campopleginae (Hymenoptera; Ichneumonidae) do Brasil. Revista Brasileira de Zoologia, 14, 649-658. https://doi.org/10.1590/S0101-81751997000300014

Greene, G. L., Leppla, N. C., \& Dickerson, W. A. (1976). Velvetbean catterpillar: a rearing procedure and artificial medium. Journal of Economic Entomology, 69, 487-488. https://doi.org/10.1093/jee/69.4.487

Hooks, C. R. R., \& Johnson, M. W. (2003). Impact of agricultural diversification on the insect community of cruciferous crops. Crop Protection, 22, 223-238. https://doi.org/10.1016/S0261-2194(02)00172-2

Inclán, D. J., \& Stireman III, J. O. (2014). A new species and synonymy of the Neotropical Eucelatoria Townsend and redescription of Myiodoriops Townsend. ZooKeys, 464, 63-97. https://doi.org/10.3897/ zookeys.464.8155

Jerez, V., Lanfranco, D., \& Andrade, B. (1977). Aspectos ecologicos de los Icneumonidos del Bosque de Quintero. Anales del Museo de Historia Natural de Valparaiso, 10, 161-168.

Kumagai, A. F. (2002). Os Ichneumonidae (Hymenoptera) da Estação Ecológica da Universidade Federal de Minas Gerais, Belo Horizonte, com ênfase nas espécies de Pimplinae. Revista Brasileira de Entomologia, 46, 189-194. https://doi.org/10.1590/S0085-56262002000200011

Kumagai, A. F., \& Graf, V. (2000). Ichneumonidae (Hymenoptera) de áreas urbana e rural de Curitiba, Paraná, Brasil. Acta Biológica Paranaense, 28, 153-168. https://doi.org/10.5380/abpr.v29i0.588

Lanfranco, D. (1974a). Contribución al conocimiento de la Ichneumofauna de la region de Magallanes (Hymenoptera-Ichneumonidae). Anales del Instituto de la Patagonia, 5, 199-208.

Lanfranco, D. (1974b). Ichneumonidos (Hymenoptera-Ichneumonidae) del Parque Nacional "Vicente Perez Rosales". Anales del Museo de Historia Natural de Valparaiso, 7, 261-267. 
Lavandero, B., Wratten, S. D., Didham, R. K., \& Gurr, G. (2006). Increasing floral diversity for selective enhancement of biological control agents, a double-edged sward? Basic and Applied Ecology, 7, 236-243. https://doi.org/10.1016/j.baae.2005.09.004

Lopes-da-Silva, M., Toma, R., Benito, N. P., Schmidt, F. G. V., Lopes, R. B., Mendonça, R. S., \& Silva, L. M. O. (2014). Ocorrência de parasitismo por Tachinidae (Diptera) em Helicoverpa armigera e Chrysodeixis includens (Lepidoptera: Noctuidae) em lavouras de soja. Anais do Congresso Brasileiro Entomologia.

Marconato, G., Dias, M. M., \& Penteado-Dias, A. M. (2008). Larvas de Geometridae (Lepidoptera) e seus parasitóides, associadas a Erythroxylum microphyllum St.-Hilaire (Erythroxylaceae). Revista Brasileira de Entomologia, 52, 296-299. https://doi.org/10.1590/S0085-56262008000200010

Menezes, E. L. A. (2005). Inseticidas botânicos: Seus princípios ativos, modo de ação e uso agrícola (Documentos 205). Embrapa Agrobiologia, Seropédica. Retrieved from https://www.agencia.cnptia. embrapa.br/recursos/doc205ID-E5DFp9Pf68.pdf

Nihei, S. S. (2015). Revision of the Neotropical Exoristini (Diptera, Tachinidae): The status of the genera Epiplagiops and Tetragrapha. Journal of Insect Scice, 15. https://doi.org/10.1093/jisesa/iev023

Nihei, S. S., \& Pavarini, R. (2011). Taxonomic redescription and biological notes on Diaugia angusta (Diptera, Tachinidae): parasitoid of the palm boring weevil Metamasius ensirostris and M. hemipterus (Coleoptera, Dryophthoridae), Zookeys, 84, 23-38. https://doi.org/10.3897/zookeys.84.756

O'Hara, J. E. (2012). World genera of the Tachinidae (Diptera) and their regional occurrence (Version 7.0, p. 75). Retrieved from http://www.nadsdiptera.org/Tach/Genera/Gentach_ver7.pdf

Onody, H. (2005). Estudo dos Campopleginae (Hymenoptera, Ichneumonidae) neotropicais com ênfase na fauna da Mata Atlântica, Brasil (Tese de Doutorado, Universidade Federal de São Carlos, São Carlos).

Onody, H. C., \& Penteado-Dias, A. M. (2006). Aiura, a new genus of Campopleginae (Hymenoptera; Ichneumonidae) from Brazil. Brazilian Journal of Biology, 66, 755-758. https://doi.org/10.1590/S1519-698 42006000400020

Onody, H. C., \& Penteado-Dias, A. M. (2016). A new species of Cryptophion (Hymenoptera: Ichneumonidae) from southeastern Brazil. Zoologia, 33. https://doi.org/10.1590/S1984-4689zool-20150101

Porter, C. (1975). Relaciones zoogeograficas y origen de la fauna de Ichneumonidae (Hymenoptera) en la provincia biogeografica del Monte del noroeste Argentino. Acta Zoologica Lilloana, 31, 175-252.

Porter, C. (1979). Ichneumonidae de Tarapacá. I. Subfamilia Ephialtinae (Hymenoptera). Idesia, 5, 157-187.

Sabrosky, C. W. (1981). A Partial Revision of the Genus Eucelatoria (Diptera, Tachinidae), Including Important Parasites of Heliothis. Technical Bulletin No. 1635 (p. 18). U.S. Department of Agriculture, USA.

Sánchez-Arias, A. D., Alcantara, B. F. M., Ordaz-Silva, S., López-Sánchez, I. V., Delgadillo-Ángeles, J. L., \& Pedro-Méndez, J. G. (2017). Parasitismo Natural De Estigmene acrea (Drury) (Lepidoptera: Arctiidae) por Gymnocarcelia ricinorum Townsend, (Diptera: Tachinidae) En El Cultivo De Fresa. Boletin Sociedad Mexicana de Entomologia, 4, 33-36.

Sandonato, D. L., Onody, H. C., \& Penteado-Dias, A. M. (2010). Fauna de Campopleginae (Hymenoptera, Ichneumonidae) em hortas orgânicas em Araraquara e São Carlos, SP, Brasil. Biota Neotropica, 10, 117-121. https://doi.org/10.1590/S1676-06032010000200014

Shennan, C. (2008). Biotic interactions, ecological knowledge and agriculture. Philosophical Transactions of the Royal Society B: Biological Sciences, 363, 717-739. http://doi.org/10.1098/rstb.2007.2180

Simões, A. M. A. (2002). Development of the tachinid parasitoid Exorista larvarum (L.) in three common Noctuidae of Azores Archipelago. The Tachinid Times, 15, 7-9.

Sosa-Gómez, D. R., Corrêa-Ferreira, B. S., Hoffmann-Campo, C. B., Corso, I. C., Oliveira, L. J., Moscardi, F., ... Roggia, S. (2010). Manual de identificação de insetos e outros invertebrados da cultura da soja (2nd ed.). Londrina: Embrapa Soja.

Sourokov, A., \& Mitchell, E. R. (2002). Laboratory biology of Chetogena scutellaris (Diptera: Tachinidae), a parasitoid of Noctuidae reared on fall armyworm and cabbage looper. Florida Entomologist, 85, 341-342. https://doi.org/10.1653/0015-4040(2002)085[0341:LBOCSD]2.0.CO;2 
Stireman, J. O. III, \& Singer, M. S. (2003a). Determinants of parasitoid-host associations: Insights from a natural tachinid-lepidopteran community. Ecology, 84, 296-310. http://doi.org/10.1890/0012-9658(2003)084[0296: DOPHAI]2.0.CO;2

Stireman, J. O. III, \& Singer, M. S. (2003b). What determines host range in parasitoids? An analysisof tachinid parasitoid community. Oecologia, 135, 629-638. http://doi.org/10.1007/s00442-003-1235-2

Stireman, J. O. III, O'Hara, J. E., \& Wood, D. M. (2006). Tachinidae: Evolution, Behavior, and Ecology. Annual Review of Entomology, 51, 525-55. http://doi.org/10.1146/annurev.ento.51.110104.151133

Tachinidae Resources. (2017). Taxonomic and host catalogue of the Tachinidae of America North of Mexico. Tachinidae Resources. Retrieved from http://www.nadsdiptera.org/Tach/Nearctic/CatNAmer/Genera/ Archytas.html

Toma, R. (2010). Contribuição ao conhecimento das espécies venezuelanas de Lespesia Robineau-Desvoidy (Diptera, Tachinidae, Exoristinae), com descrição de novas espécies. Revista Brasileira de Entomologia, 54,165-172. https://doi.org/10.1590/S0085-56262010000200002

Wood, D. M., \& Zumbado, M. A. (2010). Tachinidae (Tachinid Flies, Parasitic Flies). In B. V. Brown, et al. (Eds.), Manual of Central American Diptera (Vol. 2, Ch. 113). NRC Research Press, Ottawa.

Yu, D. S., Van Achterberg, C., \& Horstmann, K. (2012). World Ichneumonoidea 2011. Database on Flash-Drive. Ottawa, Taxapad. Retrieved from http://www.taxapad.com

\section{Copyrights}

Copyright for this article is retained by the author(s), with first publication rights granted to the journal.

This is an open-access article distributed under the terms and conditions of the Creative Commons Attribution license (http://creativecommons.org/licenses/by/4.0/). 